\title{
Professor Guenter Petzow Named to MMA Honorary Advisory Board
}

\author{
Ryan M. Deacon ${ }^{1}$
}

Published online: 24 July 2017

(C) Springer Science+Business Media, LLC and ASM International 2017

Since its founding six years ago, Metallography, Microstructure, and Analysis has benefited greatly from the guidance and counsel of its editorial advisory board. This group of distinguished individuals has championed the journal's growth, and helped $M M A$ to find its place in the technical literature. One of the board members, Professor Guenter Petzow, has recently indicated his desire to step down from his position on the advisory committee, and reduce his active role in the International Metallographic Society.

Professor Petzow has been a significant supporter of not only MMA, but also of the journal Materials Characterization, which was previously edited by MMA's advisory editor, Dr. Chris Bagnall. Professor Petzow has also been a very active volunteer for the International Metallographic Society, serving on several committees, and lending his considerable energy and creativity to improving the society.

In recognition of his significant contributions to both IMS and its journals, I am pleased to appoint Professor Petzow as the founding member of the Honorary Advisory Board for Metallography, Microstructure, and Analysis.

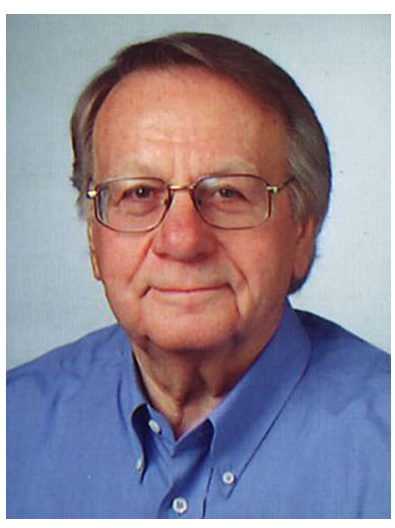

Professor Guenter Petzow

It is my hope that the journal will continue to benefit from his advice and counsel as we continue to expand and improve. On behalf of the editorial staff of $M M A$ and the Board of Directors of the International Metallographic Society, I offer my sincere gratitude for his service to our society and profession.

Ryan M. Deacon

ryan.deacon@asminternational.org

1 United Technologies Research Center, 411 Silver Lane,

East Hartford, CT 06108, USA 